\title{
OS IMPACTOS DO NOVO CÓDIGO DE PROCESSO CIVIL NA ADMISSIBILIDADE DOS RECURSOS
}

\section{IMPACTS OF THE NEW CIVIL PROCEDURE CODE ON ADMISSIBILITY OF RESOURCES}

Alexandre Máximo Oliveira ${ }^{1}$

\begin{abstract}
RESUMO
O novo Código de Processo Civil apresenta diversas modificações nos pressupostos e juízo de admissibilidade dos recursos, que influenciaram diretamente na tramitação dos processos presentes e futuros. Este trabalho busca antecipar algumas das dificuldades, teóricas e práticas, que os profissionais do direito encontraram na aplicação dos procedimentos estabelecidos no novo Código, trazendo ponderações que devem ser consideradas para compreensão das novas bases científicas buscadas pelo legislador. O baixo número de trabalhos ou de doutrina sobre o tema realça a necessidade de se estudar melhor o assunto, que está relacionado com a promessa constitucional de razoável duração do processo. No desenvolvimento do estudo, para se alcançar os objetivos propostos, foi utilizada a pesquisa teórica referente ao tema, consistindo na análise de conteúdo dos textos doutrinários e normas legais.
\end{abstract}

Palavras-chave: Recursos, Admissibilidade, Novo, Código de processo civil

\begin{abstract}
The new Civil Procedure Code introduces several changes in the assumptions and judgment of admissibility of appeals, which directly influenced the conduct of current and future processes. This paper seeks to anticipate some of the difficulties, theoretical and practical, that legal professionals found in the application of the procedures established in the new code, bringing weightings should be considered for understanding the science base sought by the legislature. The low number of papers or literature on the subject highlights the need to better study the issue, which is related to the constitutional promise of reasonable duration of the process. In preparing the study, to achieve the proposed objectives, we used the theoretical research concerning the issue, consisting of the content analysis of doctrinal texts and legal norms.
\end{abstract}

Keywords: Resources, Admissibility, New, Code of civil procedure

\footnotetext{
${ }^{1}$ Mestrado em Direito pela Universidade de Itaúna - UIT, Minas Gerais, (Brasil). Professor e Coordenador do Núcleo de Prática Jurídica pelo Centro Universitário de Patos de Minas - UNIPAM, Minas Gerais, (Brasil). E-mail: alexandre@maximoadvocacia.com.br
} 


\section{INTRODUÇÃO}

A busca por um acesso à justiça efetivo e substancial, se tornou, desde o século anterior, um dos principais temas de observação dos estudiosos do Direito.

A importância do desenvolvimento de técnicas processuais adequadas para possibilitar um acesso efetivo à justiça, tem sido progressivamente encarada como o requisito fundamental - o mais básico dos direitos humanos — de um sistema jurídico moderno e igualitário que pretenda garantir, e não apenas proclamar os direitos de todos (CAPPELLETTI, 2002, p. 9).

A construção de um Código de Processo Civil, adequado para solucionar a intensa litigiosidade existente neste novo milênio, constitui preocupação de milhares de profissionais do Direito, espalhados em diversa carreiras jurídicas, na esperança de alcançarem a promessa constitucional de razoável duração do processo $^{2}$.

A morosidade da prestação jurisdicional no Poder Judiciário brasileiro decorre, em parte, do grau de litigiosidade existente na sociedade ${ }^{3}$, que contida durante muitos anos no regime ditatorial, foi exposta com a efetivação do direito fundamental de acesso a justiça consolidado após a Constituição Federal de 1988. Provocada quantidade de recursos que se avolumam nos Tribunais pátrios.

O tema proposto decorre das novas bases científicas trazidas pelo legislador na elaboração do novo Código de Processo Civil no que tange ao juízo de admissibilidade dos recursos. A adoção de novos procedimentos e o aperfeiçoamento dos antigos, exige uma busca pelos fundamentos que foram adotados pelo legislador para solucionar discussões travadas na legislação anterior.

\footnotetext{
${ }^{2}$ No Brasil, esta preocupação deixou der ser meramente acadêmica e tópica, com a Convocação de uma Comissão de Juristas, instituída pelo Presidente do Senado Federal, pelo Ato n. 379, em setembro de 2009, com a responsabilidade de elaborar o Anteprojeto de um Novo Código de Processo Civil. Em 08 de junho de 2010, o Anteprojeto foi submetido ao Poder Legislativo, sendo que foi discutido por mais de quatro anos, com a realização audiências públicas em vários Estados Brasileiros, sugestões pela internet e a participação de diversos setores da sociedade organizada. O texto do novo Código de Processo Civil foi finalmente aprovado em 17.12.2014, e promulgado pela Presidente da República, com vetos, em 16.03.2015.

${ }^{3}$ Segundo a décima edição do Relatório Justiça em Números do Conselho Nacional de Justiça, considerando o ano base 2013, o Poder Judiciário brasileiro tinha 95 milhões de processos em tramitação.
} 
O baixo número de trabalhos ou de doutrina sobre o tema realça a necessidade de se estudar melhor o assunto, que está relacionado com a promessa constitucional de razoável duração do processo.

O novo Código de Processo Civil apresenta diversas modificações nos pressupostos e juízo de admissibilidade dos recursos, que influenciaram diretamente na tramitação dos processos presentes e futuros. Este trabalho busca antecipar algumas das dificuldades, teóricas e práticas, que os profissionais do direito encontraram na aplicação dos procedimentos estabelecidos no novo Código, trazendo ponderações que devem ser consideradas para compreensão das novas bases científicas buscadas pelo legislador.

No desenvolvimento do estudo, para se alcançar os objetivos propostos, foi utilizada a pesquisa teórica referente ao tema, consistindo na análise de conteúdo dos textos doutrinários e normas legais.

\section{INCIDÊNCIA DO PRINCÍPIO DA COOPERAÇÃO E A ALTERAÇÃO DA COMPETÊNCIA PARA REALIZAÇÃO DO JUÍZO DE ADMISSIBILIDADE DOS RECURSOS}

O recurso é o poder de provocar o reexame de uma decisão, pela mesma autoridade judiciária, ou por outra hierarquicamente superior, visando obter a sua reforma, invalidação, esclarecimento ou integração (SANTOS, 2010, p. 84).

Para o exercício regular do direito de recorrer, a parte tem que atender algumas condições impostas pelo ordenamento jurídico - aqui denominadas por pressupostos de admissibilidade - sob pena de não alcançar o reexame da decisão impugnada por outro órgão jurisdicional.

Wambier (2006, p. 150) em obra destinada ao assunto prescreve:

Sem medo de errar, pode-se fazer uma analogia entre o mecanismo que há entre os pressupostos de admissibilidade do julgamento da lide (que são especificamente, os pressupostos processuais e as condições da ação) e o 
mérito da ação, e as condições de admissibilidade de um recurso e o mérito de um recurso.

No novo Código de Processo Civil, o juízo de admissibilidade e de mérito é realizado somente pelo órgão que possui competência recursal, sendo que legislador autoriza o julgamento monocrático pelo relator do recurso, quando houver precedente firmado em súmula de Tribunais ou em julgamento de recurso especial ou extraordinário repetitivo, e ainda, em incidente de assunção de competência ou de resolução de demandas repetitivas.

No Código de Processo Civil de 1973 o juízo de admissibilidade dos recursos, em regra, é realizado pelo órgão prolator da decisão recorrida ( $a$ quo) e pelo órgão com competência recursal (ad quem).

O novo Código rompeu este sistema, atribuindo a admissibilidade dos recursos ao órgão que possui competência para reexaminar a decisão, ou seja, o órgão a quo somente recebe a petição do recurso e faculta a parte contrária a possibilidade de apresentação de resposta, sendo o recurso encaminhado para o órgão ad quem para realização do juízo de admissibilidade e juízo de mérito.

A inovação promovida na competência para realização do juízo de admissibilidade é comentada por Mello (2015, p. 2.239):

O CPC/2015 inova ao extinguir o duplo juízo de admissibilidade a que se submete o recurso de apelação no regime do CPC/1973. Com efeito, em face do que literalmente dispõe o $\S 3^{\circ}$ do art. 1010 sob análise, a apelação será remetida ao Tribunal independentemente de juízo de admissibilidade realizado pelo órgão de primeiro grau, ao qual incumbirá, apenas, o recebimento da apelação, a intimação da parte recorrida para apresentação de contrarrazões e a remessa dos autos ao órgão recursal.

Constata-se que o novo Código estabeleceu como regra geral a admissibilidade do recurso pelo órgão que possui competência recursal, já que esta opção está evidenciada no recurso de apelação ${ }^{4}$, de agravo de instrumento ${ }^{5}$, de agravo interno ${ }^{6}$, no recurso ordinário ${ }^{7}$, no recurso especial e extraordinário ${ }^{8}$, e no agravo em recurso especial e extraordinário ${ }^{9}$.

\footnotetext{
${ }^{4} \mathrm{CPC} / 2015$. Art. 1.010. A apelação, interposta por petição dirigida ao juízo de primeiro grau, conterá: [...] $\S 3^{\circ}$ Após as formalidades previstas nos $\S \S 1^{\circ}$ e $2^{\circ}$, os autos serão remetidos ao tribunal pelo juiz, independentemente de juízo de admissibilidade.

${ }^{5} \mathrm{CPC} / 2015 \mathrm{Art}$. 1.017. [...] $\S 3^{\circ} \mathrm{Na}$ falta da cópia de qualquer peça ou no caso de algum outro vício que comprometa a admissibilidade do agravo de instrumento, deve o relator aplicar o disposto no art. 932, parágrafo único.
} 
A inovação promovida coaduna com princípio da razoável duração do processo, por dois motivos: a) evita que o recurso interposto fique paralisado no órgão prolator da decisão recorrida aguardando análise da admissibilidade; b) evita a interposição de novo recurso contra a decisão do órgão a quo que realiza juízo negativo de admissibilidade.

Ocorre que a sistemática adotada pela novel legislação não agradou a todos os órgãos do Poder Judiciário. Em razão da insatisfação dos Ministros do Supremo Tribunal Federal e do Superior Tribunal de Justiça, está em tramitação no Senado Federal o Projeto de Lei n. 414/2015, apresentado pelo Senador Blairo Maggi em 01/07/15, dispondo sobre o juízo de admissibilidade do recurso extraordinário ou especial e instaurando o recurso de agravo de admissão, nos próprios autos, dessa decisão, alterando dispositivos da Lei no 13.105, de $16 / 03 / 15$.

A justificativa apresentada no Projeto de Lei n. 414/2015 é a seguinte:

É que a Lei 13.105/2015 foi promulgada retirando-se o filtro recursal que até então era realizado pela Presidência ou pela Vice-Presidência dos tribunais regionais federais e dos tribunais de justiça para o processamento do recurso especial ou extraordinário.

Sabe-se que significativo número de processos que acabaram não subindo em razão deste juízo prévio de admissibilidade.

Importante notar os dados estatísticos apurados pelo Tribunal Regional Federal da $4^{\text {a }}$ Região em 2014/2015, que em um período aproximado de 16 meses foram proferidas aproximadamente 26 mil decisões negando seguimento aos recursos extremos. Dessas decisões, somente 17 mil foram objeto de agravo para os Tribunais Superiores, ocasião em que mais de 1/3 do volume de trabalho que seria destinado aos tribunais superiores foram estancados na origem, por opção da parte (BRASIL, 2015).

\footnotetext{
${ }^{6} \mathrm{CPC} / 2015$ Art. 1.021. Contra decisão proferida pelo relator caberá agravo interno para o respectivo órgão colegiado, observadas, quanto ao processamento, às regras do regimento interno do tribunal [...] $\S 2^{\circ} \mathrm{O}$ agravo será dirigido ao relator, que intimará o agravado para manifestar-se sobre o recurso no prazo de 15 (quinze) dias, ao final do qual, não havendo retratação, o relator levá- lo-á a julgamento pelo órgão colegiado, com inclusão em pauta.

${ }^{7}$ CPC/2015. Art. 1.028. Ao recurso mencionado no art. 1.027, inciso II, alínea -b\|, aplicam-se, quanto aos requisitos de admissibilidade e ao procedimento, as disposições relativas à apelação e o Regimento Interno do Superior Tribunal de Justiça. [...] $\S 3^{\circ}$ Findo o prazo referido no $\S 2^{\circ}$, os autos serão remetidos ao respectivo tribunal superior, independentemente de juízo de admissibilidade.

${ }^{8}$ CPC/2015. Art. 1.030. Recebida a petição do recurso pela secretaria do tribunal, o recorrido será intimado para apresentar contrarrazões no prazo de 15 (quinze) dias, findo o qual os autos serão remetidos ao respectivo tribunal superior. Parágrafo único. A remessa de que trata o caput dar-se-á independentemente de juízo de admissibilidade.

${ }^{9} \mathrm{CPC} / 2015$. Art. 1.042. Cabe agravo contra decisão de presidente ou de vice-presidente do tribunal que: [...] $\S 4^{\circ}$ Após o prazo de resposta, não havendo retratação, o agravo será remetido ao tribunal superior competente.
} 
A proposta de alteração visa manter no novo Código de Processo Civil, o juízo de admissibilidade do recurso extraordinário e especial no órgão prolator do acórdão recorrido, ou seja, perante o presidente ou vice presidente do Tribunal que prolatar a decisão impugnada. Em decorrência da mencionada alteração, também se cria uma nova modalidade recursal, denominada agravo de admissão, excluindo o agravo em recurso especial e extraordinário.

É nítido que a missão institucional do Supremo Tribunal Federal e do Superior Tribunal de Justiça, atribuída pela Carta Magna de 1988, ficaria comprometida pela imposição da análise de admissibilidade de milhares de recursos excepcionais, tornando letra morta os filtros criados desde a emenda Constitucional 45/2004, furtando dos Ministros a energia que deve ser despendida para análise de violações e interpretações do ordenamento jurídico constitucional e infraconstitucional.

Se é certo que a sistemática de juízo de admissibilidade exclusivo no órgão ad quem beneficia a celeridade ${ }^{10}$ nos recursos classificados como ordinários, o mesmo não se pode dizer em razão dos recursos classificados como extraordinários, pois carecem as Cortes Superiores de material humano suficiente para analisar de admissibilidade de todos os recursos interpostos em vinte e seis Estados da federação e do Distrito Federal, incluindo processos da justiça comum, especializada e federal.

Contudo, a falha identificada no novo Código, que, certamente, será corrigida pelo legislativo, antes de sua entrada em vigor, em 18/03/2016, não esconde a substancial inovação, decorrente da adoção expressa do princípio da cooperação/colaboração no $\operatorname{artigo~} 6^{\mathbf{o}^{11}}$.

Em decorrência do princípio da cooperação, adotado expressamente pelo novo Código de Processo Civil, o relator, antes de considerar inadmissível o recurso, concederá o prazo de cinco dias ao recorrente, para que seja sanado o vício ou complementada a documentação exigível $^{12}$.

Comentam o princípio da cooperação Theodoro Júnior, Nunes, Bahia e Pedron (2015, p. 70):

Isso induz à assunção do processo como um locus normativamente condutor de uma comunidade de trabalho, na qual todos os sujeitos processuais devam atuar em viés interdependente e auxiliar, com responsabilidade, na construção dos pronunciamento judiciais e em sua efetivação. 
A contaminação do texto do novo Código pelo princípio da cooperação repercutiu diretamente no sistema recursal, vinculando, inclusive o Supremo Tribunal Federal e o Superior Tribunal de Justiça, que no julgamento do recurso especial e extraordinário devem desconsiderar vício formal de recurso tempestivo ou determinar sua correção, desde que não o repute grave $\mathrm{e}^{13}$.

Verifica-se que o processo comparticipativo ${ }^{14}$ consagra outras garantias constitucionais, como o princípio da igualdade, ao possibilitar que deficiências técnicas decorrentes da defesa das partes, que impedem os exercícios dos seus direitos e a solução de mérito da lide, possam ser corrigidas por iniciativa do juiz.

O poder do juiz de interrogar a parte para esclarecimento de questões de fato e de direito relevantes para a decisão cumpre dupla função no processo alemão e no italiano: (i) a de facilitar a obtenção de elementos de convencimento; e (ii) a de proporcionar uma assistência à parte débil, por meio do suprimento de eventual de uma defesa deficiente. Como isso, melhor defesa para as razões do litigante débil, o que, em última análise, cumpre a técnica do processo com finalidade social, e promove aquilo que se costuma qualificar com paridade real de armas. (THEODORO JÚNIOR, NUNES, BAHIA E PEDRON, 2015, p. 84).

\footnotetext{
${ }^{10}$ Segundo a Exposição de Motivos do novo Código de Processo Civil, sua elaboração orientou precipuamente por cinco objetivos, dentre eles, simplificar, resolvendo problemas e reduzindo a complexidade de subsistemas, como, por exemplo, o recursal.

${ }^{11} \mathrm{CPC} / 2015$. Art. $6^{\circ}$ Todos os sujeitos do processo devem cooperar entre si para que se obtenha, em tempo razoável, decisão de mérito justa e efetiva.

${ }^{12}$ CPC/2015. Art. 932. Incumbe ao relator: [...] III - não conhecer de recurso inadmissível, prejudicado ou que não tenha impugnado especificamente os fundamentos da decisão recorrida; [...] Parágrafo único. Antes de considerar inadmissível o recurso, o relator concederá o prazo de 5 (cinco) dias ao recorrente para que seja sanado vício ou complementada a documentação exigível.

13 Art. 1.029. O recurso extraordinário e o recurso especial, nos casos previstos na Constituição Federal, serão interpostos perante o presidente ou o vice-presidente do tribunal recorrido, em petições distintas que conterão: [...] $\S$ $3^{\circ}$ O Supremo Tribunal Federal ou o Superior Tribunal de Justiça poderá desconsiderar vício formal de recurso tempestivo ou determinar sua correção, desde que não o repute grave.

14 Expressão adotada por Humberto Theodoro Júnior, Dierle Nunes, Alexandre Bahia e Flávio Pedron para denominar o princípio da cooperação/colaboração estabelecido no artigo $6^{\circ}$ do novo Código de Processo Civil.
} 
As alterações do novo Código também fulmina a nefasta prática de jurisprudência defensiva, que visa diminuir o acervo processual dos Tribunais, com a inadmissão de recursos por excesso de formalismo. Por outro lado, fortalece o princípio do contraditório, não como uma mera garantia formal de informação e possibilidade de reação contra o julgamento de decisões, mas como uma garantia substancial de participação efetiva das partes, concomitantemente com o juiz, na construção dos provimentos jurisdicionais e solução de mérito do conflito. Do mesmo modo, expressou o legislador no texto legal a adoção do princípio da primazia da análise do mérito.

\section{PRESSUPOSTOS DE ADMISSIBILIDADE DOS RECURSOS NO NOVO CÓDIGO DE PROCESSO CIVIL E O SEU IMPACTO NO PROCESSO COLETIVO}

Para apresentação das modificações nos pressupostos de admissibilidade do recurso no novo Código de Processo Civil, será utilizada a classificação proposta por José Carlos Barbosa Moreira, que divide os pressupostos de admissibilidade em intrínsecos e extrínsecos. Do mesmo modo, Nery Júnior, considera a decisão judicial, que é objeto do recurso, para nominar os pressupostos de admissibilidade do recurso.

[...] os pressupostos intrínsecos são aqueles que dizem respeito à decisão recorrida em si mesma considerada. Para serem aferidos, leva-se em consideração o conteúdo e a forma da decisão impugnada. De tal modo que, para proferir-se o juízo de admissibilidade, toma-se o ato judicial impugnado no momento e da maneira como foi prolatado. São eles o cabimento, a legitimação para recorrer e o interesse em recorrer. Os pressupostos extrínsecos respeitam aos fatores externos à decisão judicial que se pretende impugnar, sendo normalmente posteriores a ela. Neste sentido, para serem aferidos não são relevantes dados que compõem o conteúdo da decisão recorrida, mas sim fatos a ela supervenientes. Deles fazem parte a tempestividade, a regularidade formal, a inexistência de fato impeditivo ou extintivo do poder de recorrer e o preparo (NERY JUNIOR, NERY, 2007, p. 273-274).

Assim, verifica-se que os pressupostos intrínsecos consistem no cabimento, na legitimidade e no interesse em recorrer, e os pressupostos extrínsecos, na tempestividade, no preparo e na inexistência de fatos extintivo ou impeditivo do direito de recorrer.

O cabimento é a relação de adequação entre uma decisão recorrível e o recurso que a lei aponte como próprio para impugná-la. As espécies de recursos cabíveis no novo Código de Processo Civil constam do rol do artigo $994^{15}$. 
Não há recurso que não tenha sido previsto em lei. O rol legal é taxativo, numerus clausus. Além disso, cada um serve para determinada situação. Contra sentença cabe apelação; contra decisões interlocutórias, agravo; contra decisões omissas, contraditórias e obscuras, embargos de declaração, e assim por diante. Cada recurso é típico e adequado para certas circunstâncias (GONÇALVES, 2015, p. 60-61).

Deste modo, verifica-se, em comparação ao Código de Buzaid, que o legislador excluiu das espécies recursais o recurso de agravo retido e os embargos infringentes.

As decisões judiciais passíveis de questionamento por agravo retido passaram a ser impugnadas nas razões ou contrarrazões do recurso de apelação ${ }^{16}$, flexibilizando o legislador o sistema de preclusão rígida do Código anterior, que exigia a interposição de recurso a cada decisão prolatada, sob pena de não poder discutir mais a matéria decidida.

O modelo adotado pelo legislador, consistente na possibilidade de impugnar todas as questões decidida no curso do processo somente no recurso de apelação não contribui para efetividade do processo. Constata-se a possibilidade da opção trazer tumulto a marcha do processo, provocando o retorno dos autos para primeira instância após a análise da apelação, para correção de vícios que somente foram apontados no recurso contra sentença, podendo, inclusive, eventual litigante agir com malicia para poder procrastinar a prestação jurisdicional, vez que diante de um ato processual viciado, ficará silente para o seu apontamento ao final da tramitação em primeira instância, nas razões ou contrarrazões de apelação, provocando enormes danos para a prestação jurisdicional.

\footnotetext{
${ }^{15}$ CPC/2015. Art. 994. São cabíveis os seguintes recursos: I - apelação; II - agravo de instrumento; III - agravo interno; IV - embargos de declaração; V - recurso ordinário; VI - recurso especial; VII - recurso extraordinário; VIII - agravo em recurso especial ou extraordinário; IX - embargos de divergência.

${ }^{16} \mathrm{CPC} / 2015$. Art. 1.009. Da sentença cabe apelação. $\S 1^{\circ}$ As questões resolvidas na fase de conhecimento, se a decisão a seu respeito não comportar agravo de instrumento, não são cobertas pela preclusão e devem ser suscitadas em preliminar de apelação, eventualmente interposta contra a decisão final, ou nas contrarrazões. $\S 2^{\circ}$ Se as questões referidas no $\S 1^{\circ}$ forem suscitadas em contrarrazões, o recorrente será intimado para, em 15 (quinze) dias, manifestar-se a respeito delas. [...].
} 
Entretanto, permaneceu no novo Código a possibilidade de utilização do recurso de agravo de instrumento para questionamento das decisões interlocutórias previstas no artigo 1.015, que retratam decisões que não podem aguardar o advento da sentença para o seu reexame. Neste ponto, não houve alteração do sistema de preclusão, sendo que a ausência de utilização do recurso de agravo de instrumento no momento oportuno, impede a rediscussão da matéria tratada na decisão.

As decisões que não permitem o questionamento quando da utilização do recurso de apelação, impondo a necessidade de interposição de recurso de agravo de instrumento, sob pena de preclusão, estão elencadas no artigo 1.015 do novo Codex ${ }^{17}$, optando o legislador por um modelo casuístico, com hipóteses taxativas de utilização do recurso.

Ressalta-se que este modelo casuístico não constava da redação original do anteprojeto apresentado pela Comissão de Juristas, instituída para elaborar o Anteprojeto de um Novo Código de Processo Civil (BRASIL, 2010).

As críticas ao modelo estabelecido pelo recurso de agravo de instrumento no novo Código são oriundas, inclusive, de membros que participaram da elaboração do novo Código de Processo Civil:

\begin{abstract}
Ademais, já se teve oportunidade de demonstrar os riscos da opção casuística, desde o anteprojeto, diante da percepção de que a mudança proposta não traria quase nenhuma diminuição do atual número desses recursos em trâmite e poderá gerar idas e vindas para as interlocutórias de reanálise diferida junto à apelação, em face da supressão no Senado da figura do protesto (para aquelas decisões que não caberiam o recurso em sua modalidade de instrumento), técnica prevista na redação final do projeto no CPC da Câmara dos Deputados. (THEODORO JÚNIOR, NUNES, BAHIA E PEDRON, 2015, p. 32).
\end{abstract}

\footnotetext{
${ }^{17} \mathrm{CPC} / 2015$. Art. 1.015. Cabe agravo de instrumento contra as decisões interlocutórias que versarem sobre: I tutelas provisórias; II - mérito do processo; III - rejeição da alegação de convenção de arbitragem; IV - incidente de desconsideração da personalidade jurídica; V - rejeição do pedido de gratuidade da justiça ou acolhimento do pedido de sua revogação; VI - exibição ou posse de documento ou coisa; VII - exclusão de litisconsorte; VIII rejeição do pedido de limitação do litisconsórcio; IX - admissão ou inadmissão de intervenção de terceiros; X concessão, modificação ou revogação do efeito suspensivo aos embargos à execução; XI - redistribuição do ônus da prova nos termos do art. 373, § 1o; XII - (VETADO); XIII - outros casos expressamente referidos em lei. Parágrafo único. Também caberá agravo de instrumento contra decisões interlocutórias proferidas na fase de liquidação de sentença ou de cumprimento de sentença, no processo de execução e no processo de inventário.
} 
O legislador em outras tentativas de diminuir a utilização do recurso de agravo de instrumento, realizada através das reformas promovidas no Código de Buzaid, pelas Leis 10.352/2001 e 11.187/2005, não conseguiu trazer resultados concretos e efetivos para a prestação jurisdicional. Conforme já apontava Wambier (2006, p. 86) a solução estabelecida pela Lei 10.352/2001 não conduziu a resultados satisfatórios, já que a decisão que determinava a conversão do agravo de instrumento em retido era recorrível. Do mesmo modo, no que tange a Lei 11.187/2005, mencionava a doutrinadora que -se é certo que a intenção do legislador é a de reduzir, significativamente, os casos em que o agravo deve seguir o regime de instrumento, a solução normativa não deve ensejar resultados absurdos ou contraproducentes\| (WAMBIER, 2006, p. 458).

Ignorou ainda o legislador, estudo realizado pela Universidade Federal da Bahia e pela Universidade Federal do Estado de Minas Gerais, nos respectivos Tribunais Estaduais, com a participação de diversos professores, dentre eles, Miracy Gustin, Fernando Jayme, Dierle Nunes, Fredie Didier Júnior, que em 2013, apontavam que as hipóteses taxativas para o agravo de instrumento, em nada contribuiria para simplificação e aceleração do procedimento. Vejamos:

\begin{abstract}
A dicotomia entre os dois modelos, o vigente e o do Projeto, no que tange à recorribilidade ou irrecorribilidade das decisões interlocutórias, é apenas aparente. Pois, à luz dos dados estatísticos levantados perante o TJ-BA, constata-se, com relativa clareza, que as hipóteses de irrecorribilidade do Projeto representam pouco menos de $12 \%$ dos agravos de instrumento interpostos naquele Tribunal. Ou seja, como serão mantidas as hipóteses de cabimento relativas à urgência, à execução civil, dentre outras previstas em lei, a inovação legislativa constante do NCPC vai alterar muito pouco a quantidade de recursos de agravo de instrumento existentes no TJ-BA.

$[\ldots]$

Tendo em vista os resultados da pesquisa, a inovação proposta poderá trazer mais problemas do que soluções, sobretudo por não se harmonizar com a própria sistemática do NCPC. Isso porque, no particular, o Projeto distancia o sistema recursal de impugnação das interlocutórias da lógica que regerá o processo de conhecimento (BRASIL, 2013).
\end{abstract}

Neste cenário, não andou bem o legislador ao criar um sistema casuístico para o recurso de agravo de instrumento, cuja as hipóteses de irrecorribilidade produzirão impactos inexpressivos na celeridade da tramitação do feito, e ainda, privilegiando um sistema mitigado de preclusão das decisórias interlocutórias, que permitirá uma ampla revisão destas no recurso 
de apelação, tornando complexo o processamento do recurso contra sentença, e abrindo margem para retorno do autos a primeira instância para correção de vícios identificados durante a tramitação em primeira instância.

No que tange aos embargos infringentes, sua supressão decorreu da implementação de uma técnica de julgamento, que prevê o prosseguimento do julgamento, com a ampliação do número de julgadores, toda vez que o resultado do julgamento da apelação for não unânime, podendo, eventualmente, ocorrer sua utilização na ação rescisória que rescindir a coisa julgada e no agravo de instrumento que questionar decisão de mérito ${ }^{18}$.

Mais uma vez, foi desatento o legislador, uma vez que no regime processual vigente, a utilização dos embargos infringentes ficava restrita quando o acórdão não unânime houvesse reformado, em grau de apelação, a sentença de mérito, ou houvesse julgado procedente a ação rescisória ${ }^{19}$.

A exclusão do recurso de embargos infringentes no novo Código e a inclusão da nova técnica de julgamento de recursos permitiu que todos os acórdãos de julgamento do recurso de apelação, não unânimes, independentemente de reforma de decisão mérito, ensejem, automaticamente, uma nova apreciação pelo Tribunal, com a ampliação do número de julgadores. Sem contar, a possibilidade da técnica incidir também em acórdãos de julgamento de agravos de instrumento, que apreciarem parcialmente o mérito.

\footnotetext{
${ }^{18} \mathrm{CPC} / 2015$. Art. 942. Quando o resultado da apelação for não unânime, o julgamento terá prosseguimento em sessão a ser designada com a presença de outros julgadores, que serão convocados nos termos previamente definidos no regimento interno, em número suficiente para garantir a possibilidade de inversão do resultado inicial, assegurado às partes e a eventuais terceiros o direito de sustentar oralmente suas razões perante os novos julgadores. $§ 1^{\circ}$ Sendo possível, o prosseguimento do julgamento dar-se-á na mesma sessão, colhendo-se os votos de outros julgadores que porventura componham o órgão colegiado. $\S 2^{\circ} \mathrm{O}$ s julgadores que já tiverem votado poderão rever seus votos por ocasião do prosseguimento do julgamento. $\S 3^{\circ} \mathrm{A}$ técnica de julgamento prevista neste artigo aplica-se, igualmente, ao julgamento não unânime proferido em: I - ação rescisória, quando o resultado for a rescisão da sentença, devendo, nesse caso, seu prosseguimento ocorrer em órgão de maior composição previsto no regimento interno; II - agravo de instrumento, quando houver reforma da decisão que julgar parcialmente o mérito. $\S 4^{\circ}$ Não se aplica o disposto neste artigo ao julgamento: I - do incidente de assunção de competência e ao de resolução de demandas repetitivas; II - da remessa necessária; III - não unânime proferido, nos tribunais, pelo plenário ou pela corte especial.
}

${ }^{19}$ CPC/1973. Art. 530. Cabem embargos infringentes quando o acórdão não unânime houver reformado, em grau de apelação, a sentença de mérito, ou houver julgado procedente ação rescisória. Se o desacordo for parcial, os embargos serão restritos à matéria objeto da divergência. (Redação dada pela Lei nº 10.352, de 26.12.2001). 
Assim, a alteração ao invés de eliminar a complexidade e morosidade do sistema recursal, fez com que o tempo de tramitação do recurso de apelação no Tribunal fosse aumentado e o seu julgamento estendido toda vez que ele fosse não unânime.

A alteração não passou desapercebida pela crítica doutrinária de Lanes (2015, p. 2102).

Vê-se retrocesso, pois de certo modo, foi em parte desenterrado o antigo art. 530 , legitimador dos embargos infringentes quando detectado julgamento não unânime em apelação e em ação rescisória, ou seja, aquele anterior às sensíveis modificações que advieram pela Lei 10.352/2001. Agora, como antes da indicada lei, os dois votos contrários ao entendimento minoritário, não necessitam estar reformando a decisão meritória de primeiro grau, para que assim seja desafiada a presença de outros julgadores que permitam a reversão do resultado que ficou suspenso.

Do mesmo modo, também manifestou a Associação dos Magistrados do Brasil AMB, a Associação dos Juízes Federais do Brasil - AJUFE e a Associação de Nacional dos Magistrados do Trabalho - ANAMATRA, que expediram ofício à Presidente da República pugnando pelo veto de vários artigos do novo Código de Processo Civil, dentre eles, o artigo 942 que trata da técnica de julgamento de apelações não resolvidas por unanimidade (SOUSA; DELFIN, 2015).

A legitimidade para recorrer consiste na identificação dos sujeitos que podem utilizar dos recursos no ordenamento jurídico. Neste aspecto, o novo Código não promoveu qualquer alteração, podendo interpor recurso as partes, o Ministério Público, na condição de parte ou fiscal da lei, e o terceiro prejudicado. Entretanto, aperfeiçoou a redação referente ao terceiro prejudicado

em sintonia com o próprio sistema processual que condiciona o interesse jurídico como fundamental para se intervir em uma relação jurídica processual [...] estendendo-a a hipóteses não somente relativas a um terceiro prejudicado como titular do direito, como também a um possível substituto processual do referido -terceiro prejudicadoll apto a participar da demanda enquanto tal, conforme se observa em situações triviais - v.g., sindicatos, partidos políticos etc. (GAIO JUNIOR, 2014, p. 210).

O mesmo ocorreu no interesse em recorrer, que não passou por qualquer inovação, ficando configurado quando o legitimado tenha sofrido uma sucumbência no processo, seja ela formal ou material. 
Alterações significativas foram providas no pressuposto de tempestividade, iniciando pela unificação dos prazos das espécies recursais, para o prazo de 15 dias $^{20}$. A exceção está reservada aos embargos de declaração, cujo prazo permaneceu em $05 \operatorname{dias}^{21}$.

O prazo em dobro para recorrer, antes previsto no Código de Processo Civil somente para o Ministério Público, para Fazenda Pública e para os litisconsortes representados por diferentes procuradores, foi também regulamentado para Defensoria Pública e escritórios de prática jurídica de instituições de ensino ${ }^{22}$.

Ocorre que tais benefícios não coadunam com a promessa de prestar a atividade jurisdicional em um prazo razoável, conforme crítica de Meireles (2012, p. 205):

Observem a contradição. Para se assegurar a duração razoável do processo, a lei prevê que o particular litigante se manifeste nos autos num prazo razoável (de 15 dias para contestar, por exemplo). Contudo, contraditoriamente, de quem mais se exige a realização de atos para celeridade processual, a lei concede o prazo em dobro em relação aquele assegurado ao particular. Ora, na realidade, fosse para se conceder prazos distintos, ao particular deveria ser assegurado maior prazo em relação aquele concedido ao Poder Público. Isso porque ao Estado (Fazenda Pública) cumpre agir de forma a não retardar a prestação jurisdicional, mesmo nos atos praticados enquanto parte no processo.

Em relação ao prazo em dobro concedido ao particular assistido pela Defensoria Pública, a critica é de violação ao princípio da igualdade.

Esse dispositivo em comento, antes mesmo de se violar a cláusula da duração razoável do processo, infringe o princípio da igualdade. Isso porque concede a um particular assistido pela Defensoria Pública o direito de se manifestar em prazo diverso daquele que é concedido ao particular que é patrocinado por advogado privado (MEIRELES, 2012, p. 209) ${ }^{23}$.

É inegável que nos dias atuais não se afigura mais justificável adoção pelo legislador de benefícios para a atuação do Ministério Público, Fazenda Pública, Defensoria Pública e escritórios de prática jurídica, sendo que a prática de concessão de prazos em dobro para manifestação, inclusive para recorrer, constitui uma nítida violação ao princípio da razoável duração do processo e ao princípio da igualdade, que deveria ter sido corrigida pelo legislador, especialmente por se tratar de um Código que foi elaborado com a finalidade de simplificação, celeridade e efetividade. 
O legislador estabeleceu ressalva ao prazo em dobro quando trouxe disposição no sentido de que quando a lei estabelecer prazo próprio, de forma expressa, desaparece a prerrogativa do prazo em dobro concedida ao Ministério Público, a Fazenda Pública, a Defensoria Pública e aos escritórios de prática jurídica de instituições de ensino ${ }^{24}$.

A título de exemplo da incidência da ressalva do prazo em dobro, podemos citar o artigo 198, inciso II, do Estatuto da Criança e do Adolescente ${ }^{25}$, que estabelece o prazo de 10 dias para apresentação de qualquer recurso, com exceção dos embargos de declaração. Por se tratar de prazo expresso e próprio para o Ministério Público e para defesa, desaparece o benefício do prazo em dobro.

Ainda no pressuposto de tempestividade, o recurso prematuro, vedado pela jurisprudência consolidada do Superior Tribunal de Justiça ${ }^{26}$, passou a ser admitido pelo novo Código $^{27}$.

\footnotetext{
${ }^{20} \mathrm{CPC} / 2015$. Art. 1.003. [...] $\S 5^{\circ}$ Excetuados os embargos de declaração, o prazo para interpor os recursos e para responder-lhes é de 15 (quinze) dias.

${ }^{21} \mathrm{CPC} / 2015$. Art. 1.023. Os embargos serão opostos, no prazo de 5 (cinco) dias, em petição dirigida ao juiz, com indicação do erro, obscuridade, contradição ou omissão, e não se sujeitam a preparo.

${ }^{22}$ CPC/2015. Art. 186. A Defensoria Pública gozará de prazo em dobro para todas as suas manifestações processuais. [...] $\S 3^{\circ} \mathrm{O}$ disposto no caput aplica-se aos escritórios de prática jurídica das faculdades de Direito reconhecidas na forma da lei e às entidades que prestam assistência jurídica gratuita em razão de convênios firmados com a Defensoria Pública.
}

${ }^{23}$ MEIRELES, Edilton. Duração razoável do processo e os prazos processuais no projeto do Código de Processo Civil. Revista do Processo, São Paulo, v. 207, n. 1, p.199-212, maio 2012. Mensal.

${ }^{24} \mathrm{CPC} / 2015$. Art. 180. [...]§ $2^{\circ}$ Não se aplica o benefício da contagem em dobro quando a lei estabelecer, de forma expressa, prazo próprio para o Ministério Público. Art. 183. [...] § $2^{\circ}$ Não se aplica o benefício da contagem em dobro quando a lei estabelecer, de forma expressa, prazo próprio para o ente público. Art. 186. [...] $4^{\circ} \mathrm{Não}$ se aplica o benefício da contagem em dobro quando a lei estabelecer, de forma expressa, prazo próprio para a Defensoria Pública.

${ }^{25}$ ECA. Art. 198. Nos procedimentos afetos à Justiça da Infância e da Juventude, inclusive os relativos à execução das medidas socioeducativas, adotar-se-á o sistema recursal da Lei no 5.869, de 11 de janeiro de 1973 (Código de Processo Civil), com as seguintes adaptações: [...] II - em todos os recursos, salvo nos embargos de declaração, o prazo para o Ministério Público e para a defesa será sempre de 10 (dez) dias; $\quad$ (Redação dada pela Lei ${ }^{\circ} 12.594$, de 2012).

${ }^{26}$ Súmula 418. É inadmissível o recurso especial interposto antes da publicação do acórdão dos embargos de declaração, sem posterior ratificação.

${ }^{27} \mathrm{CPC} / 2015$. Art. 218. Os atos processuais serão realizados nos prazos prescritos em lei. [...] § $4^{\circ}$ Será considerado tempestivo o ato praticado antes do termo inicial do prazo. 
O recorrente continua com o dever de realizar o preparo - pagamento das despesas com o processamento dos recursos - no ato da interposição do recurso, sendo possível sua complementação quando for insuficiente o valor ou, o recolhimento em dobro, quando ocorrer após a interposição do recurso ${ }^{28}$. A ausência de preparo leva a aplicação da pena de deserção.

Ademais, são dispensados de preparo os recursos interpostos pelo Ministério Público, pela União, pelo Distrito Federal, pelos Estados, pelos Municípios, e respectivas autarquias, e pelos que gozam de isenção legal.

No pressuposto denominado regularidade formal, mudança houve em decorrência da extinção do agravo retido de forma oral. Agora, sem exceção, todos os recursos são apresentados por petição (forma escrita) e acompanhado das razões fundamentadas para reforma (motivação) da decisão impugnada.

Os fatos extintivos ou impeditivos do direito de recorrer consistentes na renúncia, aquiescência ou desistência do recurso, são considerados pela doutrina como pressupostos negativos, que não podem ser identificados antes ou durante o processamento do recurso, pois impediram o reexame da matéria. A renúncia e a aquiescência são fatos extintivos do direito de recorrer. A desistência é um fato impeditivo do direito de recorrer.

O legislador adequou a legislação a jurisprudência do Superior Tribunal de Justiça, no sentido de continuar permitindo a desistência de recursos, entretanto, a desistência do recurso não impedirá a análise de questão cuja a repercussão geral já tenha sido reconhecida e daquela objeto de julgamento de recursos extraordinários ou especiais repetitivos ${ }^{29}$.

\footnotetext{
${ }^{28} \mathrm{CPC} / 2015$. Art. 1.007. No ato de interposição do recurso, o recorrente comprovará, quando exigido pela legislação pertinente, o respectivo preparo, inclusive porte de remessa e de retorno, sob pena de deserção. $\S 1^{\circ}$ São dispensados de preparo, inclusive porte de remessa e de retorno, os recursos interpostos pelo Ministério Público, pela União, pelo Distrito Federal, pelos Estados, pelos Municípios, e respectivas autarquias, e pelos que gozam de isenção legal. $\S 2^{\circ} \mathrm{A}$ insuficiência no valor do preparo, inclusive porte de remessa e de retorno, implicará deserção se o recorrente, intimado na pessoa de seu advogado, não vier a supri-lo no prazo de 5 (cinco) dias. $\S 3^{\circ}$ É dispensado o recolhimento do porte de remessa e de retorno no processo em autos eletrônicos. $\S 4^{\circ} \mathrm{O}$ recorrente que não comprovar, no ato de interposição do recurso, o recolhimento do preparo, inclusive porte de remessa e de retorno, será intimado, na pessoa de seu advogado, para realizar o recolhimento em dobro, sob pena de deserção. $\S 5^{\circ}$ É vedada a complementação se houver insuficiência parcial do preparo, inclusive porte de remessa e de retorno, no recolhimento realizado na forma do $\S 4^{\circ}$. $\S 6^{\circ}$ Provando o recorrente justo impedimento, o relator relevará a pena de deserção, por decisão irrecorrível, fixando-lhe prazo de 5 (cinco) dias para efetuar o preparo. $\S 7^{\circ} \mathrm{O}$ equívoco no preenchimento da guia de custas não implicará a aplicação da pena de deserção, cabendo ao relator, na hipótese de dúvida quanto ao recolhimento, intimar o recorrente para sanar o vício no prazo de 5 (cinco) dias.
} 
Questão tormentosa que o legislador perdeu a oportunidade de resolver o impasse foi quanto a possibilidade de desistência e renúncia pelo Ministério Público.

Para Leonel, sustentando estar amparado por José Carlos Barboza Moreira e Hugro Nigro Mazzili, não existe qualquer óbice para a desistência ou renúncia por parte do Ministério Público.

No sistema coletivo, a legitimação é concorrente e disjuntiva, não sendo o Ministério Público o único legitimado, podendo inclusive desistir da própria ação. Se pode desistir até da demanda, não há razão para que não possa desistir do recurso interposto, ou renunciar ao direito de recorrer ${ }^{30}$.

Por outro lado, Zavascki, amparado por Galeno Lacerda, Antônio Augusto de Melo de Camargo Ferraz, Édis Milaré, Voltaire de Lima Moraes, Ernandes Fidélis dos Santos e Hely Lopes Meirelles, destaca entendimento no sentido de não ser possível a desistência pelo Ministério Público.

Relativamente ao Ministério Público, não é aceitável o argumento segundo o qual, por não ser vedada em lei, a desistência estaria permitida. Se a proposição vale para o particular, o mesmo não se dá em relação ao Ministério Público, que, como órgão do Estado que é, obedece à regra básica do direito público: os agentes do Estado somente podem praticar atos para os quais estejam autorizados por norma legal válida. Não bastaria, portanto, ausência de proibição, com corre na atividade dos particulares ${ }^{31}$.

A solução para a questão da desistência no processo deve partir da aplicação analógica do artigo $5^{\circ}, \S 3^{\circ}$, da Lei de Ação Civil Pública ${ }^{32}$, que regulamenta a desistência de ação coletiva, impondo que o Ministério Público assuma a titularidade, na hipótese de desistência imotivada ou abandono pelo colegitimiado. Assim, parece que o legislador optou, prima facie, pela impossibilidade de desistência da ação, o que inclui também o recurso, pelo Ministério Público.

\footnotetext{
${ }^{29} \mathrm{CPC} / 2015$. Art. 998. O recorrente poderá, a qualquer tempo, sem a anuência do recorrido ou dos litisconsortes, desistir do recurso. Parágrafo único. A desistência do recurso não impede a análise de questão cuja repercussão geral já tenha sido reconhecida e daquele objeto de julgamento de recursos extraordinários ou especiais repetitivos.

${ }^{30}$ LEONEL, Ricardo de Barros. Manual do Processo Coletivo. 2. ed. São Paulo: Revista dos Tribunais, 2011, p. 399.

${ }^{31}$ ZAVASCKI, Teori Albino. Processo Coletivo: Tutela de Direitos e Tutela Coletiva de Direitos. 5. ed. São Paulo: Revista dos Tribunais, 2011, p. 141/142.
} 
Sobre a questão da desistência manifestam Almeida e Almeida:

[...] a desistência infundada ou o abandono da ação coletiva impõe controle por parte dos outros legitimados ativos e especialmente do Ministério Público (art. $5^{\circ}, \S 3^{\circ}$, da LACP), que deverá, quando infundada a desistência, assumir a titularidade da ação. Se a desistência for levada a efeito pelo órgão do Ministério Público, o juiz, dela discordando, poderá aplicar analogicamente o disposto no art. 28 do CPP, submetendo a desistência ou o abandono ao conhecimento e à apreciação do chefe da respectiva instituição do Ministério Público ${ }^{33}$.

No que tange a renúncia do direito de recorrer pelo Ministério Público, verifica-se também sua impossibilidade, por ser sua legitimação extraordinária, portanto, não poderia renunciar direito que não lhe pertence.

\section{CONCLUSÕES}

O novo sistema recursal estabelecido pelo novo Código de Processo Civil, especialmente no que tange às regras de admissibilidade, está voltado para ser um instrumento de efetivação dos direitos fundamentais, vez que construído sob a égide de valores constitucionais que buscam a construção de um Estado Democrático e Social de Direito.

As falhas do novo Código apontadas neste trabalho não são suficientes para comprometer a evolução trazida pela nova legislação no instrumento de efetivação de direitos individuais e coletivos.

O Estado Democrático e Social de Direito foi beneficiado com o reforço legislativo que impõe a necessidade de participação de todos os sujeitos do processo na construção de normas jurídicas para o caso concreto.

\footnotetext{
${ }^{32}$ LACP. Art. $5^{\circ}$. [...] $§ 3^{\circ}$ Em caso de desistência infundada ou abandono da ação por associação legitimada, o Ministério Público ou outro legitimado assumirá a titularidade ativa. (Redação dada pela Lei no 8.078, de 1990).

33 ALMEIDA, Gregorio Assagra de; ALMEIDA, Flávia Vigatti Coelho de. O Direito Processual Coletivo e a Proposta de Reforma do Sistema das Ações Coletivas no Código de Defesa do Consumidor no Brasil. Revista Luso-brasileira de Direito do Consumo, Curitiba, v. 2, n. 3, p.11-74, set. 2012. Trimestral.
} 
A eliminação de formalismos excessivos que impediam o exercício do direito ao duplo grau de jurisdição, contribuiu para que o novo Código alcançasse um dos seus objetivos, o de simplificação e solução de problemas do sistema recursal que impediam o cidadão de acesso aos direitos fundamentais individuais e coletivos.

Contudo, o sucesso do novo Código dependerá da sensibilidade dos profissionais do direito na compreensão das novas bases científicas do processo estabelecidas pelo legislador, que rompeu dogmas do modelo anterior, no sentido de buscar uma prestação jurisdicional em tempo razoável, justa e efetiva.

\section{REFERÊNCIAS}

ALMEIDA, Gregório Assagra de. Direito Processual Coletivo Brasileiro: Um novo ramo do direito processual civil. São Paulo: Saraiva, 2003.

ALMEIDA, Gregorio Assagra de; ALMEIDA, Flávia Vigatti Coelho de. O Direito Processual Coletivo e a Proposta de Reforma do Sistema das Ações Coletivas no Código de Defesa do Consumidor no Brasil. Revista Luso-brasileira de Direito do Consumo. Curitiba, v. 2, n. 3, p.11-74, set. 2012. Trimestral.

BRASIL. SECRETARIA DE REFORMA DO JUDICIÁRIO. Avaliação do impacto das modificações no regime do recurso de agravo e proposta de simplificação do sistema recursal do CPC. Brasília: Ministério da Justiça, 2013.

BRASIL. SENADO FEDERAL. PLS - Projeto de Lei do Senado no 414 de 2015. 2015. Disponível em: <http://www.senado.leg.br/atividade/materia/detalhes.asp?p_cod_mate=122069>. Acesso em: 17 jul. 2015.

GAIO JÚNIOR, Antônio Pereira. Teoria Geral dos Recursos: Breve Análise e Atualizações à Luz do PL 8.046/2010. Revista do Processo, São Paulo, v. 228, n. 1, p.207-237, fevereiro 2014. Mensal. 
GOMES JÚNIOR, Luiz Manoel. Curso de Direito Processual Civil Coletivo. 1. ed. Rio de Janeiro: Forense, 2005.

GOnÇAlves, Marcos Vinicius Rios Gonçalves. Novo Curso de Direito Processual Civil. 10. ed. São Paulo: Saraiva, 2015, 2 v.

LANES, Julio Cesar Goulart. Da ordem dos processos no tribunal. In: WAMBIER, Teresa Arruda Alvim et al. Breves Comentários ao Novo Código de Processo Civil. São Paulo: Revista dos Tribunais, 2015. p. 2102-2107.

LEONEL, Ricardo de Barros. Manual do Processo Coletivo. 2. ed. São Paulo: Revista dos Tribunais, 2011.

MEIRELES, Edilton. Duração razoável do processo e os prazos processuais no projeto do Código de Processo Civil. Revista do Processo, São Paulo, v. 207, n. 1, p.199-212, maio 2012. Mensal.

MELLO, Rogerio Licastro Torres de. Da apelação. In: WAMBIER, Teresa Arruda Alvim et al. Breves Comentários ao Novo Código de Processo Civil. São Paulo: Revista dos Tribunais, 2015. p. 2235-2248.

NERY JUNIOR, Nelson; NERY, Rosa Maria de Andrade. Código de Processo Civil comentado e legislação extravagante. 10. ed. São Paulo: Revista dos Tribunais, 2007.

SALIBA, Aziz Tiffi; ALMEIDA, Gregório Assagra de; GOMES JÚNIOR, Luiz Manoel. Direitos Fundamentais e sua Proteção nos Planos Interno e Internacional. Belo Horizonte: Arraes, 2010. 2 v.

SALIBA, Aziz Tiffi; ALMEIDA, Gregório Assagra de; GOMES JÚNIOR, Luiz Manoel. Direitos Fundamentais e sua Proteção nos Planos Interno e Internacional. Belo Horizonte: Arraes, 2010. 268 p. 1 v.

SANTOS, Moacir Amaral. Primeiras Linhas de Direito Processual Civil. 24. ed. São Paulo: Saraiva, 2010, 3 v.

SOUSA, Diego Crevelin de; DELFINO, Lúcio. As associações de magistrados e o veto do NCPC no tocante ao contraditório e ao dever de fundamentação - O que está em 
Jogo? 2015. ISSN 2446-7405. Disponível em: <http://emporiododireito.com.br/asassociacoes-de-magistrados-e-o-veto-do-ncpc-no-tocante-ao-contraditorio-e-ao-dever-defundamentacao-o-que-esta-em-jogo-diego-crevelin-de-sousa-e-lucio-delfino/>. Acesso em: 14 jul. 2015.

THEODORO JÚNIOR, Humberto; NUNES, Dierle; BAHIA, Alexandre Melo Franco; PEDRON, Flávio Quinaud. Novo CPC - Fundamentos e Sitematização. 2. ed. Rio de Janeiro: Forense, 2015.

ZAVASCKI, Teori Albino. Processo Coletivo: Tutela de Direitos e Tutela Coletiva de Direitos. 5. ed. São Paulo: Revista dos Tribunais, 2011.

WAMBIER, Teresa Arruda Alvim. Os Agravos no CPC Brasileiro. 4. ed. São Paulo: Revista dos Tribunais, 2006.

WAMBIER, Teresa Arruda Alvim et al. Breves Comentários ao Novo Código de Processo Civil. São Paulo: Revista dos Tribunais, 2015. 